\title{
Large centric diatoms allocate more cellular nitrogen to photosynthesis to counter slower RUBISCO turnover rates
}

\author{
Yaping Wu ${ }^{1,2}$, Jennifer Jeans ${ }^{1}$, David J. Suggett ${ }^{3}$, Zoe V. Finkel ${ }^{1}$ and Douglas A. Campbell ${ }^{1}$ * \\ 'Environmental Science and Biology, Mount Allison University, Sackville, NB, Canada \\ 2 State Key Laboratory of Marine Environmental Science, Xiamen University, Xiamen, China \\ ${ }^{3}$ Climate Change Cluster, University of Technology Sydney, Sydney, NSW, Australia
}

Edited by:

Jacob Carstensen, Aarhus

University, Denmark

Reviewed by:

Kevin John Flynn, Swansea

University, UK

Jeffrey William Krause, Dauphin

Island Sea Lab, USA

*Correspondence:

Douglas A. Campbell, Department

of Biology, Mount Allison University,

63B York St., Sackville, NB E4L1G7,

Canada

e-mail:dcampbel/@mta.ca
Diatoms contribute $\sim 40 \%$ of primary production in the modern ocean and encompass the largest cell size range of any phytoplankton group. Diatom cell size influences their nutrient uptake, photosynthetic light capture, carbon export efficiency, and growth responses to increasing $p \mathrm{CO}_{2}$. We therefore examined nitrogen resource allocations to the key protein complexes mediating photosynthesis across six marine centric diatoms, spanning 5 orders of magnitude in cell volume, under past, current and predicted future $p \mathrm{CO}_{2}$ levels, in balanced growth under nitrogen repletion. Membrane bound photosynthetic protein concentrations declined with cell volume in parallel with cellular concentrations of total protein, total nitrogen and chlorophyll. Larger diatom species, however, allocated a greater fraction (by 3.5-fold) of their total cellular nitrogen to the soluble Ribulose-1,5-bisphosphate Carboxylase Oxygenase (RUBISCO) carbon fixation complex than did smaller species. Carbon assimilation per unit of RUBISCO large subunit $\left(C \mathrm{RbcL}^{-1} \mathrm{~s}^{-1}\right)$ decreased with

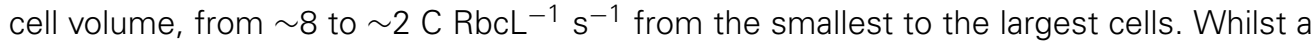
higher allocation of cellular nitrogen to RUBISCO in larger cells increases the burden upon their nitrogen metabolism, the higher RUBISCO allocation buffers their lower achieved RUBISCO turnover rate to enable larger diatoms to maintain carbon assimilation rates per total protein comparable to small diatoms. Individual species responded to increased $p \mathrm{CO}_{2}$, but cell size effects outweigh $p \mathrm{CO}_{2}$ responses across the diatom species size range examined. In large diatoms a higher nitrogen cost for RUBISCO exacerbates the higher nitrogen requirements associated with light absorption, so the metabolic cost to maintain photosynthesis is a cell size-dependent trait.

Keywords: Coscinodiscus, diatom, ocean acidification, photosynthesis, resource allocation, RUBISCO, size scaling, Thalassiosira

\section{INTRODUCTION}

Nitrogen is essential to life as a major constituent of proteins, nucleic acids, and other macromolecules. In photosynthetic organisms, nitrogen is particularly required for building the abundant complexes mediating photosynthetic carbon assimilation (Dortch et al., 1984; Campbell et al., 2003; Falkowski et al., 2008; Shi and Falkowski, 2008). These nitrogen-rich protein complexes are required for harvesting light as well as driving photosynthetic electron flow that generates the energy and reducing power for inorganic nutrient assimilation, including $\mathrm{CO}_{2}$ fixation by Ribulose-1,5-bisphosphate Carboxylase Oxygenase (RUBISCO). Nitrogen availability in turn operates as the proximal limiting factor for phytoplankton carbon assimilation (Gruber and Galloway, 2008; Moore et al., 2013) in much of the modern ocean. Phytoplankton span a wide size range (Finkel et al., 2010). Under steady state growth, smaller cells have higher rates of nutrient diffusional delivery and lower cellular nutrient requirements for growth (Pasciak and Gavis, 1974; Gavis, 1976; Finkel et al., 2010; Marañón et al., 2013). Consequently, smaller cells dominate nitrogen-limited regions whereas larger cells are typically constrained to well mixed waters where nitrogen and other nutrients are replete (Irwin et al., 2006), although some large species exploit nitrogen limited waters through symbiotic $\mathrm{N}_{2}$ fixation (Foster et al., 2011). Larger phytoplankton cells also incur significant optical packaging effects (Falkowski, 1981; Morel and Bricaud, 1981; Kirk, 1994; Finkel, 2001), which lower the photons absorbed per unit of pigment-protein complex. These changes in optical performance decrease the return of captured photons per unit of metabolic nitrogen invested into pigment protein complexes (Raven, 1984). After the captured photons initiate charge separation in a photosystem, the electrons flow along an electron transport chain comprised of abundant protein complexes, to deliver reductant for the Calvin Cycle to generate the Ribulose-1,5-bisphosphate acceptor molecules for carbon fixation by RUBISCO (Ribulose-1,5-bisphosphate Carboxylase Oxygenase). Some fraction of the reductant is then ultimately retained in assimilated organic material (Kroon and Thoms, 2006; Kromkamp et al., 2008; Suggett et al., 2009; Halsey et al., 2010, 2013).

Seawater $p \mathrm{CO}_{2}$ concentrations are currently too low to saturate RUBISCO carboxylation activity via passive $\mathrm{CO}_{2}$ diffusion 
into the cell (Badger et al., 1998; Tortell et al., 2000) and phytoplankton thus employ carbon concentrating mechanisms (CCMs) to increase the $\mathrm{CO}_{2}$ concentration around their RUBISCO complexes (Raven et al., 2011, 2014). This need for CCMs is particularly pronounced in larger cells where $\mathrm{CO}_{2}$ diffusion is limited by a smaller surface area to volume ratio (Giordano et al., 2005; Wu et al., 2014). RUBISCO represents a moderate fraction $(\sim 2-5 \%)$ of total protein in marine phytoplankton (Brown et al., 2008; Losh et al., 2013; Li et al., 2014; Young et al., 2015) which, combined with $\mathrm{C}$ assimilation rates, mean that achieved Rubisco catalytic carboxylation turnover rates $(\mathrm{C}$ $\mathrm{RbcL}^{-1} \mathrm{~s}^{-1}$ ) in phytoplankton are generally faster than achieved rates in terrestrial plants. Such high achieved rates of carboxylation, at least in the smallest (nano-pico) phytoplankton, are in part attributable to taxonomic differences in RUBISCO catalytic properties (Badger et al., 1998; Young et al., 2012) as well as the structure and operation of CCMs (Losh et al., 2013; Raven, 2013) that likely impose substantial energy and macromolecular costs for phytoplankton to meet their $\mathrm{CO}_{2}$ requirements in the current ocean. As such, increased $p \mathrm{CO}_{2}$ availability via ocean acidification could potentially afford cells a means to lower these costs (Rost et al., 2008; Hopkinson et al., 2011; Wu et al., 2014). However, experiments simulating elevated $p \mathrm{CO}_{2}$ predicted for future oceans demonstrate variable growth responses across phytoplankton (Tortell and Morel, 2002; Schippers et al., 2004; Boelen et al., 2011; Gao et al., 2012; McCarthy et al., 2012; Li and Campbell, 2013) since interacting factors including light (Gao et al., 2012), nutrient limitation (Beardall et al., 2009), taxa (Langer et al., 2006), and cell size (Wu et al., 2014) can strongly influence the net growth outcomes under ocean acidification.

Diatoms contribute $\sim 40 \%$ of productivity in the modern ocean, and span the widest size range of any phytoplankton group, from several $\mu \mathrm{m}$ to several $100 \mu \mathrm{m}$ in cell diameter (Finkel et al., 2010). Within the diatoms, fewer than 50 species contribute $>90 \%$ of all diatom biomass globally, with centric species dominating (LeBlanc et al., 2012). With increasing cell volume across species, diatoms exhibit a decrease in many key traits, notably growth rate, light capture per chlorophyll, photosynthesis rates per unit chlorophyll- $a$ and susceptibility to photoinactivation of Photosystem II (Mullin et al., 1966; Burkhardt et al., 1999; Finkel, 2001; Marañón et al., 2007, 2013; Key et al., 2010). It is, however, unknown how these size-scaling patterns interact with (re) distributions of nitrogen amongst the catalytic complexes governing $\mathrm{CO}_{2}$ assimilation and growth, and whether size-scaling in resource allocations alter in response to elevated $p \mathrm{CO}_{2}$. We recently found (Wu et al., 2014) that increased $p \mathrm{CO}_{2}$ differentially stimulates the growth of larger vs. smaller centric diatoms, apparently through a release of diffusional limitations upon $\mathrm{CO}_{2}$ delivery to the surfaces of larger cells. We therefore grew 6 strains of marine centric diatoms, spanning five orders of magnitude in cell volume, under $3 p \mathrm{CO}_{2}$ levels, with growth-saturating light and nutrient repletion, to investigate interactive effects of cell size and $p \mathrm{CO}_{2}$ on photosynthetic performance and resource allocations of cellular nitrogen quotas. We determined nitrogen investment into core photosynthetic constituents across the species and $p \mathrm{CO}_{2}$ range, and analyzed in parallel how changing macromolecular investments offset changes in the achieved photosynthetic turnover rates of the abundant catalytic complexes mediating photosynthesis.

\section{MATERIALS AND METHODS SPECIES, CULTURE CONDITIONS, SAMPLING AND GROWTH RATES}

Six marine centric diatom strains, Thalassiosira pseudonana (CCMP 1335); Thalassiosira oceanica (CCMP 1003); Thalassiosira guillardii (CCMP 988); Thalassiosira weissflogii (CCMP 1336); Thalassiosira punctigera (CCAP 1085/19) and Coscinodiscus wailesii (CCMP 2513) were maintained in mid-exponential growth through semi-continuous culturing at $20^{\circ} \mathrm{C}$ (as per Wu et al., 2014) in 1 L flasks. Cultures were illuminated with cool fluorescent tubes at a photon flux density of $350 \mu \mathrm{mol} \mathrm{m}^{-2} \mathrm{~s}^{-1}$, measured with Li-Cor spherical PAR sensor in the center of the incubation bottle $(8 \times 8 \times 16 \mathrm{~cm})$, under a 12:12 light:dark cycle, and always sampled $6 \mathrm{~h}$ after lights on. After the initial measurement of light levels in the center of the flask, we did not perform further light measures as the cultures grew, but the cultures were optically thin and the light level was saturating for growth of these species under these conditions (data not shown). The analyses in this paper draw upon the same culture experiments and some of the underlying data sets supporting (Wu et al., 2014), but include data from an additional species Thalassiosira oceanica (CCMP 1003).

Nutrient replete $\mathrm{f} / 2$ media was made using artificial seawater prepared with a total alkalinity (TA) of $\sim 2300 \mu \mathrm{mol} \mathrm{kg}^{-1}$, at three different $\mathrm{pH}(8.42,8.16$, and 7.90$)$ corresponding to $p \mathrm{CO}_{2}$ levels of ca. 190, 380, and 750 ppmv (Riebesell et al., 2010; Wu et al., 2014) and filtered to remove debris. The dissolved inorganic carbon (DIC) concentration in the media was measured with an infrared gas analyzer (QuBit, Canada) (McCarthy et al., 2012) and absolute $p \mathrm{CO}_{2}$ subsequently computed using $\mathrm{CO}_{2} \mathrm{SYS}$ software (Pierrot et al., 2006) from the known values of DIC, $\mathrm{pH}$, salinity, and alkalinity of the media. Culture vessels were sealed to avoid gas exchange with the atmosphere, and maintained at low biomass with chlorophyll a $<10 \mu \mathrm{g} \mathrm{L}^{-1}$ by regular dilution with pre-equilibrated medium. Using this approach, culture $\mathrm{pH}$ variability remained within $0.05 \mathrm{pH}$ units of the target levels throughout the growth experiments. Flasks were manually agitated 4-5 times daily and distributed arbitrarily within the growth chamber.

Daily samples from the different $p \mathrm{CO}_{2}$ cultures were fixed with Lugol's acid solution for determination of growth rate and cell size, with analyses within a week of fixation. Species with diameters $<40 \mu \mathrm{m}$ were counted with a Coulter Counter (Multisizer 3, Beckman) using the filtered media as a blank. Larger species were counted under the microscope using a Sedgwick Rafter chamber. The cell specific growth rate $\left(\mu, d^{-1}\right)$ for each of the strains was determined by ordinary least squares linear regression of $\ln$ cell density, corrected for culture dilutions with media, over time. Cell volume for all species was estimated from linear dimensions from images taken with a camera attached to a light microscope calibrated with a micrometer, using Image-J software and assuming the cells were cylinders. For all samples a minimum of 100 cells were measured.

After at least eight rounds of cell division with steady growth rate (Wu et al., 2014) to ensure acclimation to the $p \mathrm{CO}_{2}$ regime, 
cell samples for further analyses were harvested by mild vacuum filtration onto glass fiber filters $(0.22 \mu \mathrm{m}$ pore size, Whatman; vacuum pump at $0.05-0.06 \mathrm{MPa})$. Filters were pulled dry of bulk media but were not further rinsed for most analyses. During harvest about half of the culture volume was taken, across multiple sub-samples for different analyses. Cells on filters were flash frozen in liquid nitrogen and stored at $-80^{\circ} \mathrm{C}$ until later analyses of protein composition ( $25 \mathrm{~mm}$ filters) or CN elemental analyses (13 mm pre-combusted filters). Each combination of taxa and $p \mathrm{CO}_{2}$ was cultured independently in at least 3 separate flasks. All subsequent analyses and data transformations were conducted independently using matched samples and measures taken at the same sampling time from each flask separately. Final plotted points present the average of the determinations from each flask. In this way we avoided propagation of errors in the multi-step data transformations.

\section{PROTEIN QUANTITATION AND NITROGEN RESOURCE ALLOCATION ESTIMATES}

Total protein was extracted from the cells on the frozen glass fiber filters using an FastPrep-24 with the $24 \times 2$ rotor (MPBio). Each frozen filter was transferred to a $2 \mathrm{~mL}$ tube containing bead lysing matrix D (MPBio) and $700 \mu \mathrm{L}$ of extraction buffer (140 mM TRIS base, $100 \mathrm{mM}$ TrisHCL, $75 \mathrm{mM}$ LDS, $0.5 \mathrm{mM}$ EDTA, $0.4 \mathrm{mM}$ protease inhibitor (AEBSF, BioShop), 10\% w/v glycerol). The FastPrep was set to run at $6.5 \mathrm{~m} / \mathrm{s}$ for three 1 -min cycles. Samples were held on ice for $1 \mathrm{~min}$ between each cycle. Following cell lysis, each sample was centrifuged for $3 \mathrm{~min}$ at $10,000 \times \mathrm{g}$ and the supernatant assayed for total protein concentration using the BioRad DC protein assay kit with the mixed protein preparation Bovine Gamma Globulin (Pierce) standards of known concentration.

RUBISCO, Photosystem II (PSII), Cytb 6 f, and Photosystem I (PSI) protein complex contents were estimated using quantitative immunoblotting of representative subunits RbcL, PsbA, PetC, and $\mathrm{PsaC}$ respectively (Brown et al., 2008), by comparison to four point calibrated protein quantitation standard curves for each specific antibody (AgriSera, AS03-037, and AS01-017S; AS05-084 and AS01-016S; AS08 330 and AS08 330S, AS10 939 and AS04 042S). The secondary antibody goat anti-rabbit IgG was used for all blots in a dilution of 1: 50,000 (ImmunoReagents Inc, lot 14-122-042810).

Cells were harvested onto $13 \mathrm{~mm} \mathrm{GF/F} \mathrm{filter} \mathrm{for} \mathrm{measure-}$ ment of total particulate organic nitrogen, which was assumed to be equivalent to cellular nitrogen, measured using an elemental analyzer (VarioIIIEL, Elementar), and normalized to cell counts (Wu et al., 2014). The fraction of total $\mathrm{N}$ allocated to RUBISCO, to Photosystem II and to the summed protein complexes of the photosynthetic system was estimated using molar quantitations of Chl a and $\mathrm{Chl} c$ by absorbance spectrophotometry (Jeffrey and Humphrey, 1975), and the representative protein subunits PsbA, PsbD, PetC, PsaC, and RbcL by quantitative immunoblotting. We multiplied the molar content of each indicator molecule by its molecular nitrogen content. We estimated nitrogen contents for each protein complex as the sum of all amino acid nitrogen atoms in the protein subunit amino acid sequences predicted from the genome of Thalassiosira pseudonana (Armbrust et al., 2004), multiplied by the stoichiometry for conserved subunits within the complex as determined from crystal structures of PSII (Umena et al., 2011) (for PsbD or PsbA), the Cytochrome $b_{6} f$ complex (Baniulis et al., 2008) (for PetC), the PSI complex (Amunts et al., 2010) (for PsaC) or the RUBISCO complex (Mizohata et al., 2002) (for RbcL). To estimate the nitrogen allocation to the fucoxanthin-chlorophyll protein antenna complex (FCP) we used a content of two Chl c per FCP monomer (Premvardhan et al., 2010) to estimate the molar content of FCP monomers, and multiplied by the nitrogen content of a representative FCP protein monomer (Nagao et al., 2013) based upon the protein sequence (FCP8 Thalassiosira pseudonana NCBI XP_002290137.1). It should be noted that this approach of summed nitrogen allocation to the photosynthetic system is conservative since we did not include the ATP synthase complex, nor protein complexes mediating carbon concentration nor the Calvin Cycle aside from RUBISCO.

To compare our elemental analyses of cellular $\mathrm{C}$ and $\mathrm{N}$ to photosynthetic parameters, the electron equivalent content of the accumulated $\mathrm{C}$ and $\mathrm{N}$ per biovolume was estimated as:

$$
\begin{aligned}
& {\text { assimilated } \mathrm{e}^{-} \text {cell volume }}^{-1} \\
& \quad=\left\{\left(\mathrm{C} / \text { cell } \times 4 \mathrm{e}^{-} / \mathrm{C}\right)+\left(\mathrm{N} / \text { cell } \times 10 \mathrm{e}^{-} / \mathrm{N}\right)\right\} / \mathrm{V}\left(\mu \mathrm{m}^{3} \text { cell }^{-1}\right)
\end{aligned}
$$

$\mathrm{C} /$ cell and N/cell were estimated from elemental analyses of particulate organic carbon or particulate organic $\mathrm{N}$ and cell counts. To the extent that our cultures contained non-living particulate debris (Agusti and Sanchez, 2002) our estimates of C \& N assimilation rates will be exaggerated. The source for assimilated $\mathrm{C}$ in our cultures is dissolved $\mathrm{CO}_{2}$ which requires a minimum of 4 $\mathrm{e}^{-} / \mathrm{C}$ for reductive assimilation into biomass, although this value is likely an underestimate since diatoms accumulate $\mathrm{C}$ in the form of lipids (Halsey et al., 2010, 2013). The source for assimilated $\mathrm{N}$ was dissolved $\mathrm{NO}_{3}^{-}$which requires a minimum of $10 \mathrm{e}^{-} / \mathrm{N}$ for reductive assimilation into biomass.

\section{PHOTOSYNTHETIC PARAMETERS}

The PSII electron transport rate $\left(\mathrm{e}^{-} \bullet \mathrm{PSII}^{-1} \bullet \mathrm{s}^{-1}\right)$ during the $12 \mathrm{~h}$ illuminated growth period was estimated (Suggett et al., 2004, 2009) based on photosynthetic parameters measured via FIRe fluorometry (Satlantic) as:

$$
\begin{aligned}
\text { Electron transport rate } & \left(\mathrm{e}^{-} \bullet \mathrm{PSII}^{-1} \bullet \mathrm{s}^{-1}\right) \\
& =\mathrm{PPFD} \bullet \sigma_{\mathrm{PSII}^{\prime}} \bullet \Phi_{\mathrm{PSII}^{\prime}} / \Phi_{\mathrm{PSII}} \bullet \mathrm{A}
\end{aligned}
$$

Where PPFD is the growth photon flux $(350 \mu$ mol photon $\left.\mathrm{m}^{-2} \mathrm{~s}^{-1}\right)$ measured with a Walz microspherical quantum sensor (Walz, Germany). $\sigma_{\text {PSII }}^{\prime}\left(\mathrm{m}^{2}\right.$ quanta $\left.^{-1}\right)$ is the PSII effective absorption cross section (Kolber et al., 1998) measured with a background actinic light approximately equivalent to the growth light level. $\sigma_{\mathrm{PSII}}^{\prime}$ is estimated by fast repetition rate fluorometry induction (Laney, 2003) with a blue light emitting diode source from the FIRe fluorometer and thus was corrected to the white growth light using a spectral correction factor for diatom absorbance of blue vs. white light (Suggett et al., 2009). $\Phi_{\mathrm{PSII}^{\prime}}$ 
is the PSII photochemical efficiency under growth light, while $\Phi_{\text {PSII }}$ is the maximum PSII efficiency in a dark-acclimated state. The factor A converts $1.0 \mathrm{~mol}$ photon absorbed by PSII to $1.0 \mathrm{~mol}$ electron generated by PSII (Suggett et al., 2009).

Apparent carbon assimilation per RUBISCO $\left(\mathrm{C} \mathrm{RbcL}^{-1} \mathrm{~s}^{-1}\right)$ was estimated as:

$$
\begin{aligned}
& \text { RUBISCO turnover rate }\left(\mathrm{C} \mathrm{RbcL}^{-1} \mathrm{~s}^{-1}\right) \\
& =\left(\mathrm{C} \text { cell }^{-1}\right) \bullet\left(\mathrm{e}^{\mu}-1\right) \bullet\left(\text { cell RbcL }{ }^{-1}\right) \bullet 2
\end{aligned}
$$

C cell ${ }^{-1}$ was estimated from elemental analyses of particulate organic carbon normalized to cell counts, $\mu$ was the cell specific exponential growth rate $\left(\mathrm{s}^{-1}\right)$, and $\mathrm{RbcL}$ was from immunoquantitation data normalized to cell counts. This estimator is based upon net assimilated carbon per cell, and upon cellular growth rate integrated over a full 12:12 diel illumination cycle. Carbon assimilation is actually restricted to the illuminated fraction of the day, and thus we also include the factor of 2 to account for carbon assimilation $\mathrm{s}^{-1} \mathrm{RbcL}^{-1}$ during the illuminated fraction of the 12:12 diel cycle. This likely underestimates actual carbon fixation per RUBISCO during the illuminated period, since we neglect $\mathrm{C}$ lost from the cell through respiration or release of extracellular products (López-Sandoval et al., 2013), but as noted above, any contribution of non-living particulate organic carbon will exaggerate the apparent $\mathrm{C}$ living cell ${ }^{-1}$. The protein-specific electron generation rate $\left(e^{-} \mu g\right.$ protein $\left.{ }^{-1} s^{-1}\right)$ and the protein specific carbon assimilation rate $\left(\mathrm{C} \mu \mathrm{g}\right.$ protein $\left.{ }^{-1} \mathrm{~s}^{-1}\right)$ were then derived from the PSII electron transport rate and the apparent carbon assimilation per RUBISCO, both normalized to cellular protein content.

\section{RESULTS}

Total protein concentration per unit biovolume decreased with increasing cell volume, from $\sim 0.37 \times 10^{-6} \mu \mathrm{g}$ protein $\mu \mathrm{m}^{-3}$ for the smallest species, T. pseudonana, to $\sim 8 \times 10^{-9} \mu \mathrm{g}$ protein $\mu \mathrm{m}^{-3}$ for the largest species, C. wailesii, (Figure 1A). The extracted protein quantified through the dye binding assay represented $88 \pm 7 \%(n=89, \pm 95 \%$ confidence interval $)$ of the particulate organic nitrogen from the same cultures, determined using elemental analyses. The ratio of extracted protein to particulate nitrogen varied somewhat among the species. In particular, in the largest species Coscinodiscus wailesii detected protein represented $50 \pm 9 \%(n=9, \pm 95 \%$ confidence interval) of total (particulate) nitrogen. We are currently pursuing this issue to determine whether the variation is biological, technical, or both. For subsequent analyses, levels of protein complexes are expressed as number of complexes per cell, or as the fraction of cellular (particulate) nitrogen allocated to the complex, and issues of protein quantitation cancel out in the data transformations.

The concentrations of photosynthetic complexes per unit biovolume also declined with increasing cell volume (Figures 1B-E),

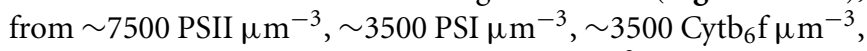
and $\sim 9500$ RUBISCO (L8S8 complex) $\mu \mathrm{m}^{-3}$ for the smallest species, down to $\sim 130$ PSII $\mu \mathrm{m}^{-3}, \sim 170$ PSI $\mu \mathrm{m}^{-3}, 110 \mathrm{Cytb}_{6} \mathrm{f}$ $\mu \mathrm{m}^{-3}$, and $\sim 960$ RUBISCO $\mu \mathrm{m}^{-3}$ for the largest species. We did not find significant effects of $p \mathrm{CO}_{2}$ on the model 2 regression slopes (Figure 1), which parameterise the size-scaling for each complex; $\left(\log _{10}(\mathrm{Y})=\mathrm{b} * \log _{10}(\right.$ cell volume $)+\mathrm{Y}$ intercept $)$. Thus, a single size-scaling model was used to describe the cell size dependency for each protein pool across all $p \mathrm{CO}_{2}$ treatments pooled; specifically $b=-0.349 \pm 0.010$ ( $\pm 95 \%$ confidence intervals) for total protein (Figure 1A); $-0.306 \pm 0.007$ for Chl a (Figure 1B); $-0.347 \pm 0.013$ for PSII (Figure 1D), $-0.256 \pm$ 0.009 for $\mathrm{Cytb}_{6} \mathrm{f}$ (Figure 1E) and $-0.317 \pm 0.021$ for PSI (Figure 1F). RUBISCO, in contrast, showed a significantly smaller size scaling exponent $(b=-0.223 \pm 0.012$, Figure 1C), showing that relatively more of the total protein pool was allocated to RUBISCO as cell size increases.

The fraction of total cellular nitrogen allocated to the summed photosynthetic complexes increased with cell volume, from the smaller species to larger species (Figure 2A; Table 1). In spite of this increased relative allocation to photosynthesis, the cell specific growth rates across the range of species decreased significantly with cell size (Wu et al., 2014) with scaling exponents of -0.071 for cells growing under $190 \mathrm{ppmv} p \mathrm{CO}_{2},-0.064$ under 380 ppmv $p \mathrm{CO}_{2}$ and -0.052 under $750 p \mathrm{CO}_{2}$. We detected $p \mathrm{CO}_{2}$ effects upon protein allocations in individual species; notably, the photosynthetic $\mathrm{N}$-fraction in T. oceanica and T. pseudonana increased with elevated $p \mathrm{CO}_{2}$ treatments (Figure 2A) but showed no consistent trend for larger species (Figure 2A). The total nitrogen-fraction allocated to PSII ranged from 0.003 to 0.016 and increased significantly under elevated $\mathrm{pCO}_{2}$ conditions in the smallest species, T. oceanica and T. pseudonana $(p<0.05)$ (Figure 2B). The RUBISCO N-fraction ranged widely from 0.01 to 0.08 , and increased with cell volume (Table 1 ) consistent with the size scaling of cellular RUBISCO content per $\mu \mathrm{m}^{-3}$ relative to total protein concentration (above, Figures 1A,C). Interestingly, under our nitrogen replete growth conditions, there was no correlation between growth rate and the fraction of cellular nitrogen allocated to photosynthesis nor to RUBISCO (data not shown). We are currently conducting analogous experiments under nitrogen limitation to pursue this issue.

PSII electron transfer rates estimated from chlorophyll fluorescence parameters in the light Equation (2), ranged from $\sim 330$ $\mathrm{e}^{-}$PSII $^{-1} \mathrm{~s}^{-1}$ in the smallest species, T. pseudonana, down to $\sim 150 \mathrm{e}^{-}$PSII $^{-1} \mathrm{~s}^{-1}$ in the largest species examined, $C$. wailesii (Figure 3A), as a consequence of packaging effects on excitation delivery to PSII (Figure 4). The apparent $\mathrm{C}$ assimilated per RUBISCO Equation (3) decreased from $\sim 8 \mathrm{C} \mathrm{RbcL}^{-1} \mathrm{~s}^{-1}$ in the smallest species down to $\sim 2 \mathrm{C} \mathrm{RbcL}^{-1} \mathrm{~s}^{-1}$ in the largest species (Figure 3B). Thus, the decrease in achieved turnover with increasing cell size was greater for RUBISCO than for PSII. The apparent RUBISCO turnover rate was significantly lower under elevated $p \mathrm{CO}_{2}$ for T. oceanica and T. weissflogii $(p<0.05)$ (Figure 3B, Table 1). PSII electron generation normalized to total protein did not exhibit any general trend with cell volume but did exhibit $p \mathrm{CO}_{2}$ effects for individual species (Figure 3C, Table 1). Across the size spectrum, carbon assimilation rates normalized to total cellular protein did not show a trend from small to large diatoms (Figure 3D, Table 1), since large species generally allocated more of their cellular nitrogen into RUBISCO, which countered the lower apparent turnover rate of their RUBISCO complexes (Figure 3B). 

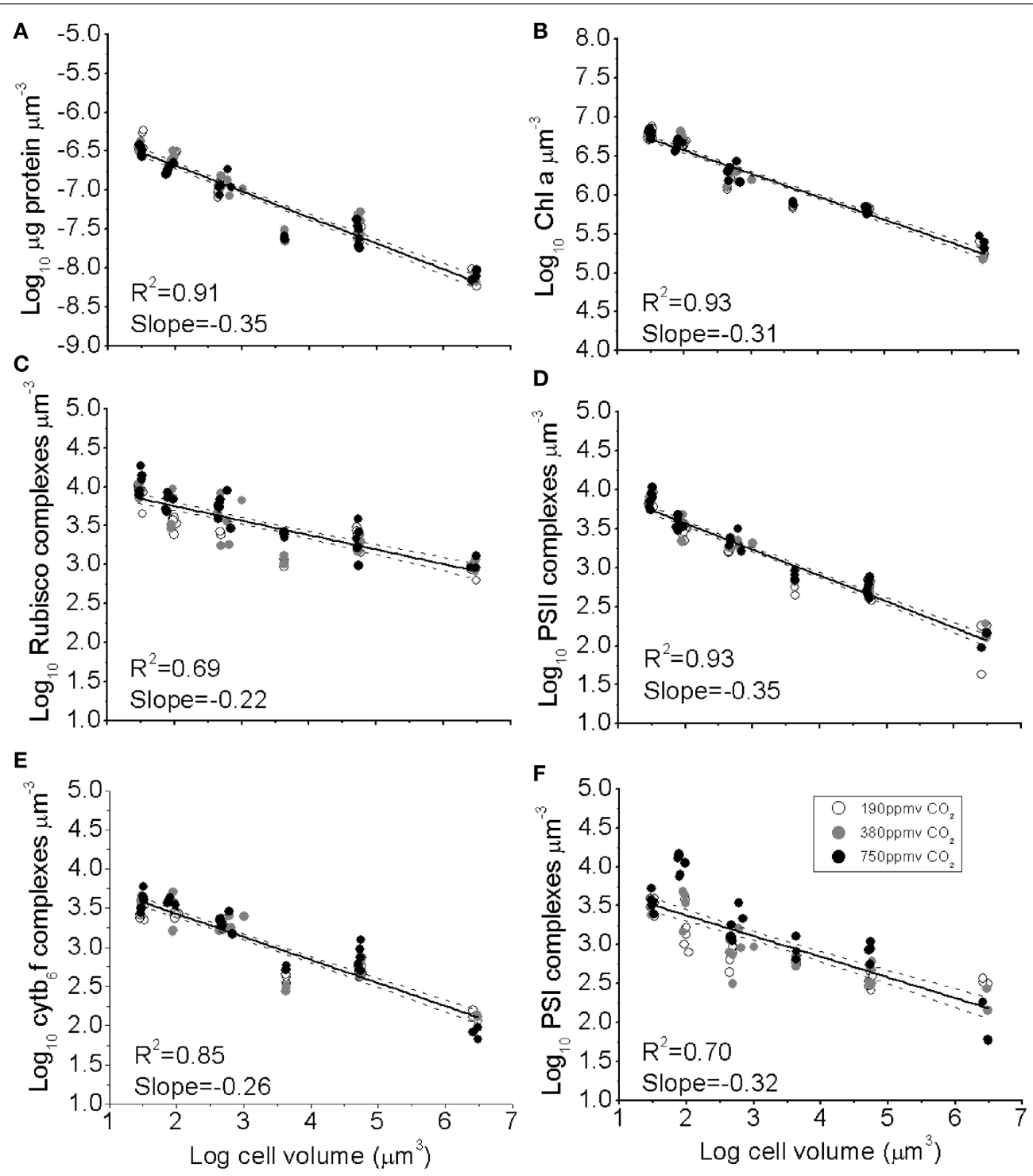

FIGURE 1 | (A) The $\log _{10}$ of cellular concentration of total protein, (B) Chl a, (C) RUBISCO complexes, (D) Photosystem II complexes, (E) Cytb $f$ complexes, and (F) Photosystem I complexes plotted as functions of $\log _{10}$ cell volume. Cultures were grown under $\mathrm{pCO}_{2} 190$ ppmv (open symbols);

380 ppmv (shaded symbols) or 750 ppmv (black symbols). Solid lines indicate pooled regressions through data from all $\mathrm{pCO}_{2}$ levels. Dotted lines indicate the $95 \%$ confidence band on the regressions, $n=3-6$ for each point.

A measure of PSII light capture capacity, the effective absorption cross section serving PSII ( $\left.\sigma_{\text {PSII }}\right)$, decreased from $320 \mathrm{~A}^{2}$ $\mathrm{PSII}^{-1}$ in the smallest species down to $130 \mathrm{~A}^{2} \mathrm{PSII}^{-1}$ in the largest species (Figure 4A). In contrast, the molar ratio of $\mathrm{Chl}$ a (Figure 4B) and Chl c (Figure 4C) to PSII reaction center content varied amongst species, with an average of $\sim 1000$ mol Chla: mol PSII, and 220 mol Chlc: mol PSII (Figure 4C), but with no significant trend with cell size. We found no consistent $p \mathrm{CO}_{2}$ effects for these light capture capacity parameters.

Carbon accumulated per generated electron (carbon $\mathrm{e}^{-1}$ ), varied from 0.11 to 0.28 across species (Figure 5A), with no consistent trends observed with cell size or with $p \mathrm{CO}_{2}$ (Table 1). A regression of accumulated electron equivalents invested to assimilated $\mathrm{N}$ and $\mathrm{C}$ per cell volume Equation (1) vs. electrons generated by PSII per cell volume $\left(\mathrm{e}^{-} \mu \mathrm{m}^{-3} \mathrm{~s}^{-1}\right)$ shows a ratio of assimilated organic matter conserving $\sim 95 \%$ of the predicted electrons generated, across the range of diatom sizes (Figure 5B).

\section{DISCUSSION}

We grew a size spectrum of marine centric diatoms under nutrient replete and light-saturated growth at three levels of $p \mathrm{CO}_{2}$. As expected (Mullin et al., 1966; Finkel, 2001; Marañón et al., 2007, 2013) the cellular concentrations of total protein, chlorophyll and the membrane bound photosynthetic complexes Photosystem II, Photosystem I and Cytochrome $\mathrm{b}_{6} \mathrm{f}$ all declined with increasing cell volume, with similar negative scaling exponents. RUBISCO, however, showed a less negative size scaling, so that larger diatoms allocated a larger fraction of their total protein toward RUBISCO, 


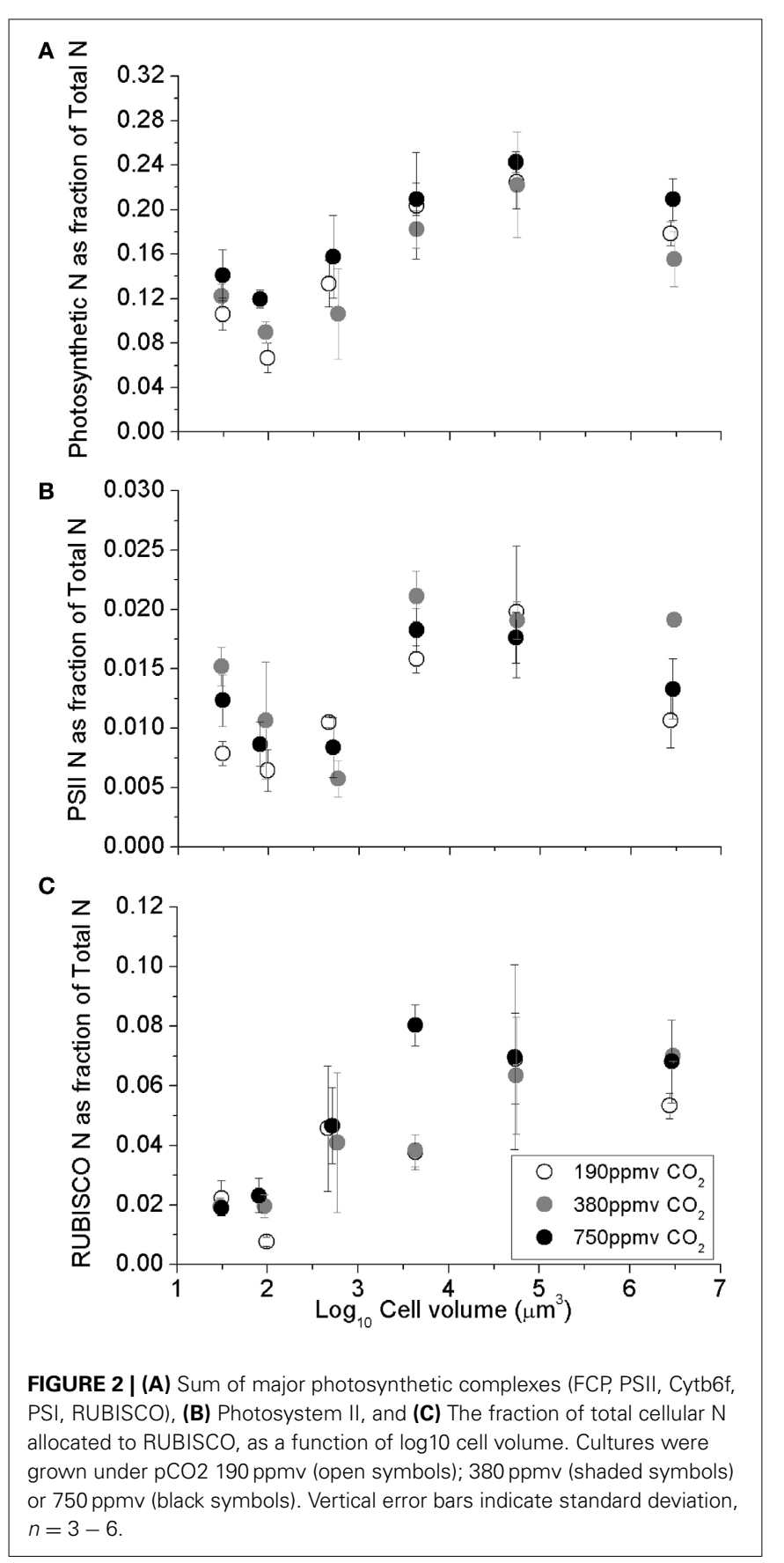

which in turn drove up the fraction of their total nitrogen allocated to their summed photosynthetic system. As with previous studies (Losh et al., 2013; Li et al., 2014; Young et al., 2015), RUBISCO represented only $\sim 2 \%$ of total cellular nitrogen in the smaller diatoms but increased to $\sim 8 \%$ in the larger diatoms (Figure 2C; Table 1). Thus, bigger diatoms make a greater investment of cellular nitrogen into carbon-assimilation capacity relative to photosynthetic electron generation, compared to smaller diatoms.

Increased $p \mathrm{CO}_{2}$ differentially stimulated growth rates by up to $15 \%$ in the largest of these centric diatoms (Wu et al., 2014). In our relatively short-term acclimatory $p \mathrm{CO}_{2}$ manipulation experiment we observed significant nitrogen allocation responses to $p \mathrm{CO}_{2}$ in some species. For example the fraction of total $\mathrm{N}$ allocated to the photosynthetic complexes increased with increased $p \mathrm{CO}_{2}$ in the small species T. oceanica and T. weissflogii (Figure 2A), although at our level of replication these changes did not generate significant correlations with growth rate. Such species-specific responses are consistent with the growing evidence of variable responses to $p \mathrm{CO}_{2}$ availability across taxa, even within closely related phytoplankton taxonomic groups (Trimborn et al., 2009, 2013; Brading et al., 2013; Gao and Campbell, 2014). Nevertheless, increased $\mathrm{CO}_{2}$ did not significantly change the size scaling of nitrogen allocations to the photosynthetic system complexes across our size range of centric diatoms. This generalized size scaling pattern across $p \mathrm{CO}_{2}$ levels suggest that the size-dependent increase in nitrogen costs to maintain $\mathrm{C}$-assimilation outweighs any changes in costs associated with changing $p \mathrm{CO}_{2}$ (Raven et al., 2014).

To assess comparative physiological returns upon nitrogen investments across the diatom size spectrum and $p \mathrm{CO}_{2}$, we estimated PSII electron transport per PSII complex, following Suggett et al. (2009), but using PsbA protein content as a proxy for the content of functional PSII. As expected given the optical packaging effects that decrease effective absorption cross sections with increasing diatom cell size (Figure 4) (Kirk, 1994; Finkel, 2001; Key et al., 2010; Wu et al., 2014), achieved electron transport per PSII decreased significantly with increasing cell size. In parallel, we used the cellular growth rate, carbon per cell, and cellular RbcL protein content to estimate the achieved carbon assimilation per RUBISCO active site. As with (Losh et al., 2013; Young et al., 2015), the smaller diatoms showed apparent carbon assimilation rates per RUBISCO close to the catalytic turnover maxima expected for RUBISCO (Badger et al., 1998; Badger and Bek, 2007) but these apparent rates declined with increasing cell size.

We propose initial, non-exclusive hypotheses to explain the cell size-dependent decline in apparent $\mathrm{C}$ assimilation per RUBISCO.

(i) We observed a significant $p \mathrm{CO}_{2}$ enhancement of growth rate of $\sim 15 \%$ under 750 ppmv $p \mathrm{CO}_{2}$ in the largest centric diatoms (Wu et al., 2014), which was explicable via relief from passive $\mathrm{CO}_{2}$ diffusion limitation to the cell surface of larger diatoms. An increase in RUBISCO protein allocation in larger cells could be driven to compensate for a sizedependent limitation on $\mathrm{CO}_{2}$ diffusion. As the immediate sink for $\mathrm{CO}_{2}$, higher cellular RUBISCO content could drive faster $\mathrm{CO}_{2}$ uptake per cell. Although we have not yet tested pennate diatoms, their higher surface to volume ratios could alter these responses to $p \mathrm{CO}_{2}$.

(ii) The decline in achieved RUBISCO performance could reflect negative scaling of metabolic rates with cell size (Burkhardt et al., 1999; Finkel, 2001; Marañón et al., 2013), which could limit the rate of metabolic regeneration of the Ribulose1,5-bisphosphate acceptor molecule for RUBISCO carbon fixation (Mott et al., 1984; Gotoh et al., 2010).

(iii) Since our C-assimilation estimates are based upon retained particulate organic carbon, an increase in extracellular carbon release from larger diatoms, or a size-dependent increase in respiratory losses to support metabolic needs, 
Table 1 | Results of Two-Way ANOVA, testing if $p \mathrm{CO}_{2}$ or cell size had individual or interactive effects on key parameters.

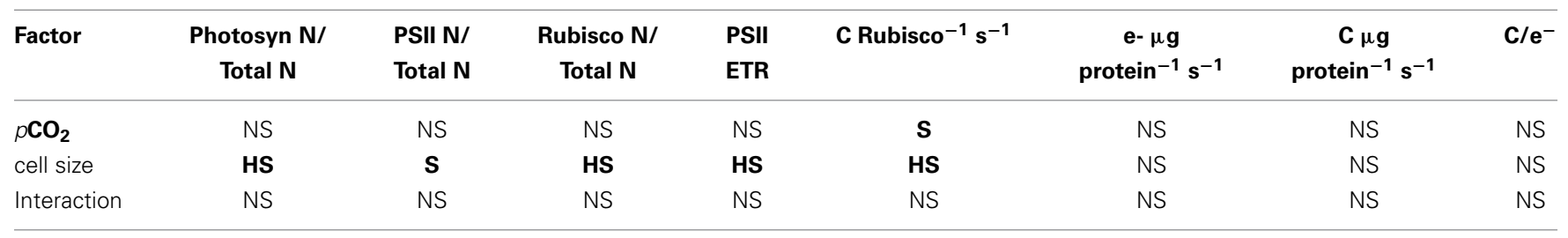

$n=3-6$ for each factor combination. NS, refers to $p$-values that were not significant $(p>0.05)$, S, significant $0.05>p>0.001$, or HS, highly significant $\left(p<1 \times 10^{-6}\right)$.

A

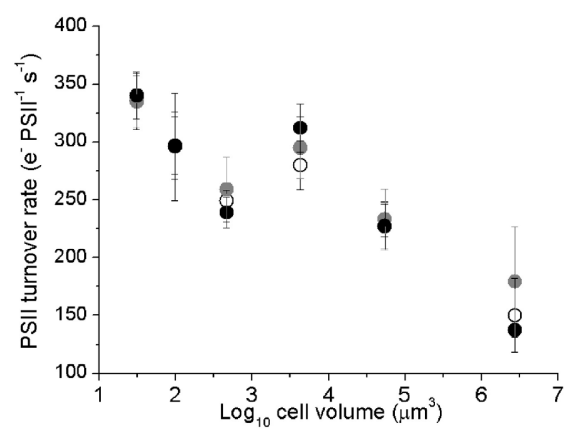

C

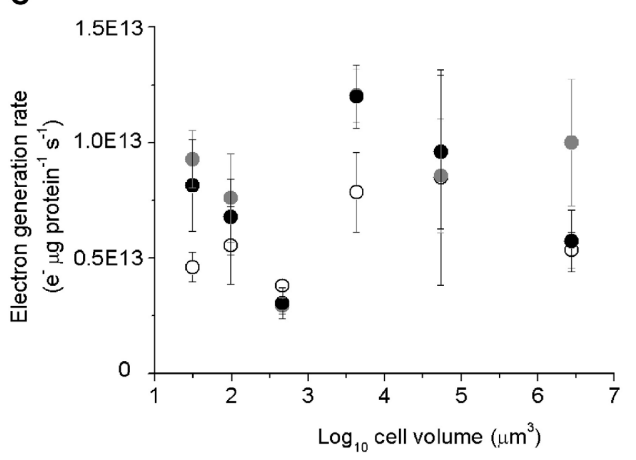

FIGURE 3 | (A) The Photosystem II electron turnover rate, (B) apparent carbon assimilation rate per RUBISCO catalytic site, (C) electron generation rate per total protein, and (D) apparent carbon assimilation rate per total

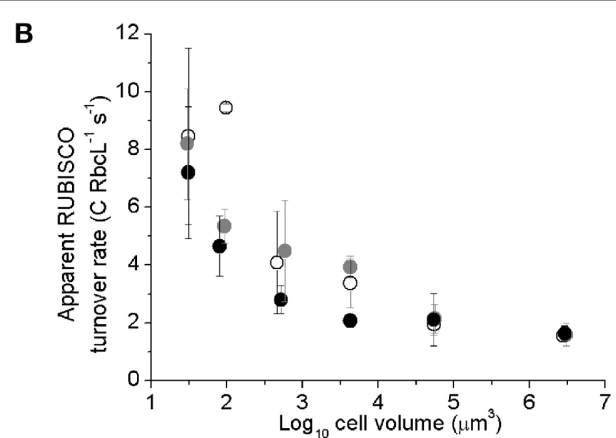

D

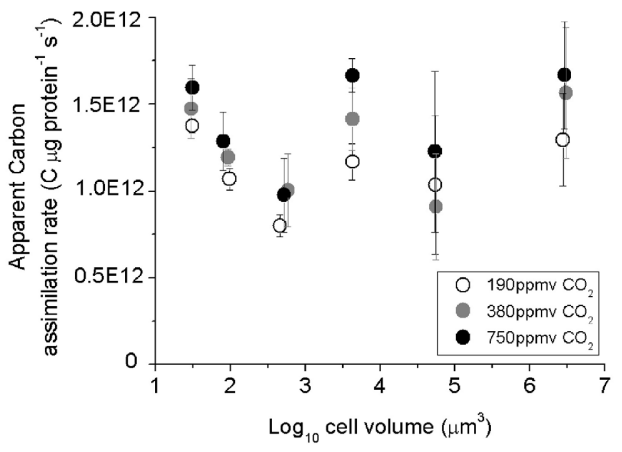

protein, plotted vs. $\log _{10}$ cell volume. Cultures were grown under $\mathrm{pCO}_{2} 190$ ppmv (open symbols); 380 ppmv (shaded symbols) or 750 ppmv (black symbols). Vertical error bars indicate standard deviation, $n=3-6$. could lower the apparent C assimilation per RUBISCO, although our consistent ratio of accumulated electrons to generated electrons across the cell size spectrum argues against this scenario. If larger diatoms experienced a disproportionate increase in respiratory losses, we would expect a decrease in the ratio of accumulated to generated electrons, but we did not see such a decrease, consistent with previous discussions (Marañón et al., 2013).

(iv) Our cultures were growing under nutrient repletion, the C:N was around 6.7:1 with no consistent $p \mathrm{CO}_{2}$ effects (Wu et al., 2014), so the increased allocation to RUBISCO in larger cells could reflect a size-dependent relative increase in luxury accumulation of RUBISCO protein, that in turn lowers achieved performance per unit RUBISCO. Such luxury protein accumulation could relate to increased vacuolization in larger species (Stolte and Riegman, 1995). A comparable experiment with small and large centric diatoms under nitrogen-limited chemostats to limit luxury accumulation is now underway to test this hypothesis.

(v) Micro-evolutionary changes in RUBISCO structure/function (Young et al., 2012) could separate small from large diatoms. We compared the RbcL (large subunit of RUBISCO) sequences across our panel of diatoms (NCBI gi118411104, gi315320529, gi98990579, gi98990561, gi98990581, gi98990595, gi329343318) as well as RbcS (small subunit of RUBISCO) sequences available for the studied species or con-generics (NCBI gi327258980, gi327258982, gi315320528, gi283569001, gi468111925). As expected, the sequences are highly conserved across the species with no amino acid differences apparent within the active site nor within the RbcL:RbcL homodimer interface surfaces. There are, however, suggestive amino acid point changes within regions annotated as the heterodimer $\mathrm{RbcL}: \mathrm{RbcS}$ dimer interfaces, including a change in $\mathrm{RbcS}$ 


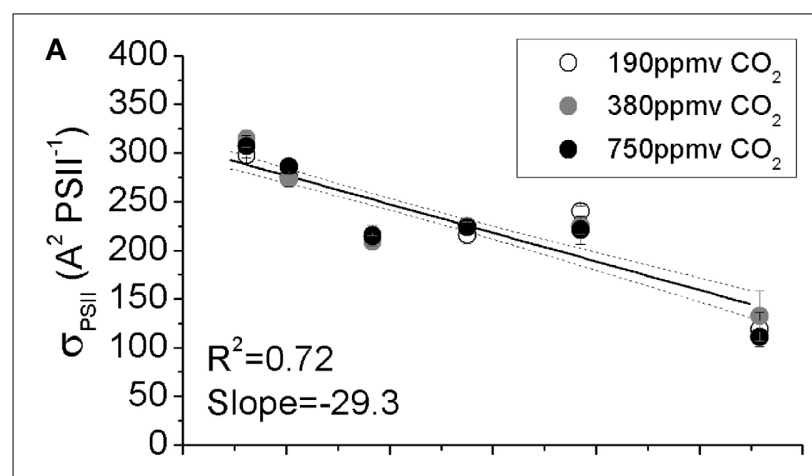

B
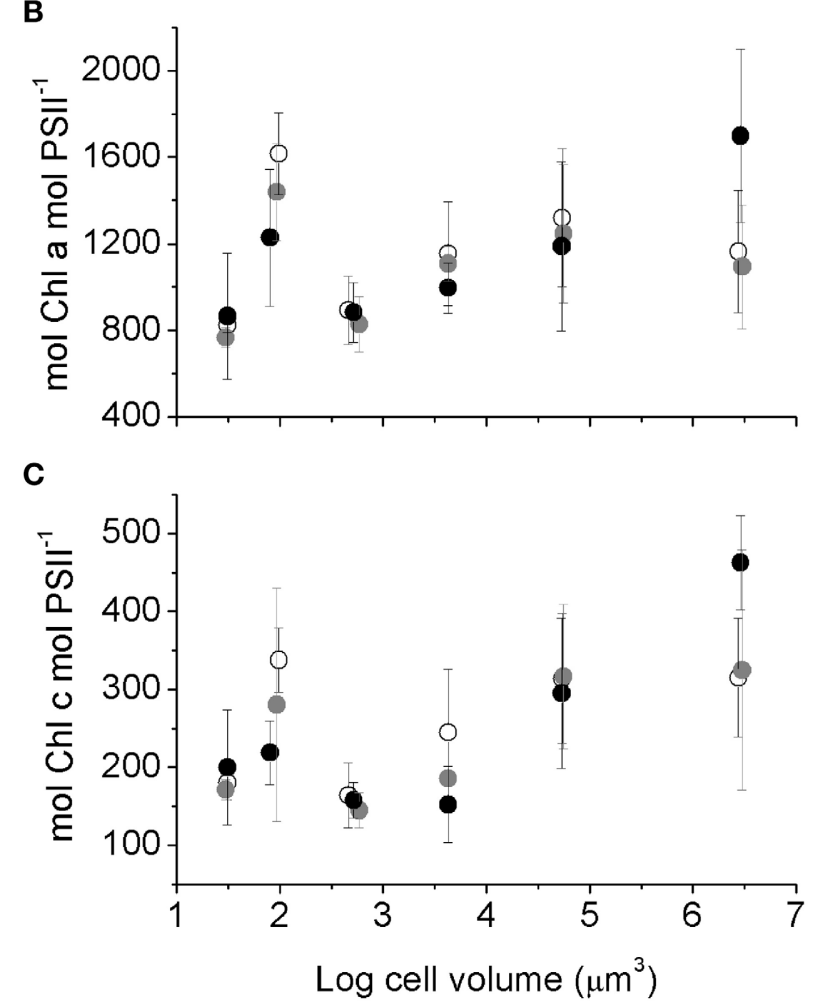

FIGURE 4 | (A) Effective blue light absorbance cross section for Photosystem II, (B) Chl a PSII-1 (C) Chl c PSII ${ }^{-1}$ plotted vs. $\log _{10}$ cell volume. The significant decrease in $\sigma_{P S / /}$ with increasing cell size (A) reflects optical packaging effects because Chl per PSII (B,C) does not decline with cell size. Solid line indicates pooled linear regression for samples from the three $\mathrm{pCO}_{2}$ levels. Dotted lines indicate the $95 \%$ confidence band on the regression. Cultures were grown under $\mathrm{pCO}_{2}$ 190 ppmv (open symbols); 380 ppmv (shaded symbols) or 750 ppmv (black symbols). $n=3-6$.

at amino acid 46 from NYWEL (amino acid sequence) conserved across the smaller Thalassiosira lineages (NCBI gi327258980, gi327258982, gi315320528, gi283569001) compared to SYWEL in an RbcS sequence from a larger Coscinodiscus (NCBI gi468111925).

Further analyses of a broader range of diatom RbcS sequences for which we had cell size estimates $(n=24)$ (Finkel, 2007) demonstrated that the 18 taxa with the NYWEL sequence at amino

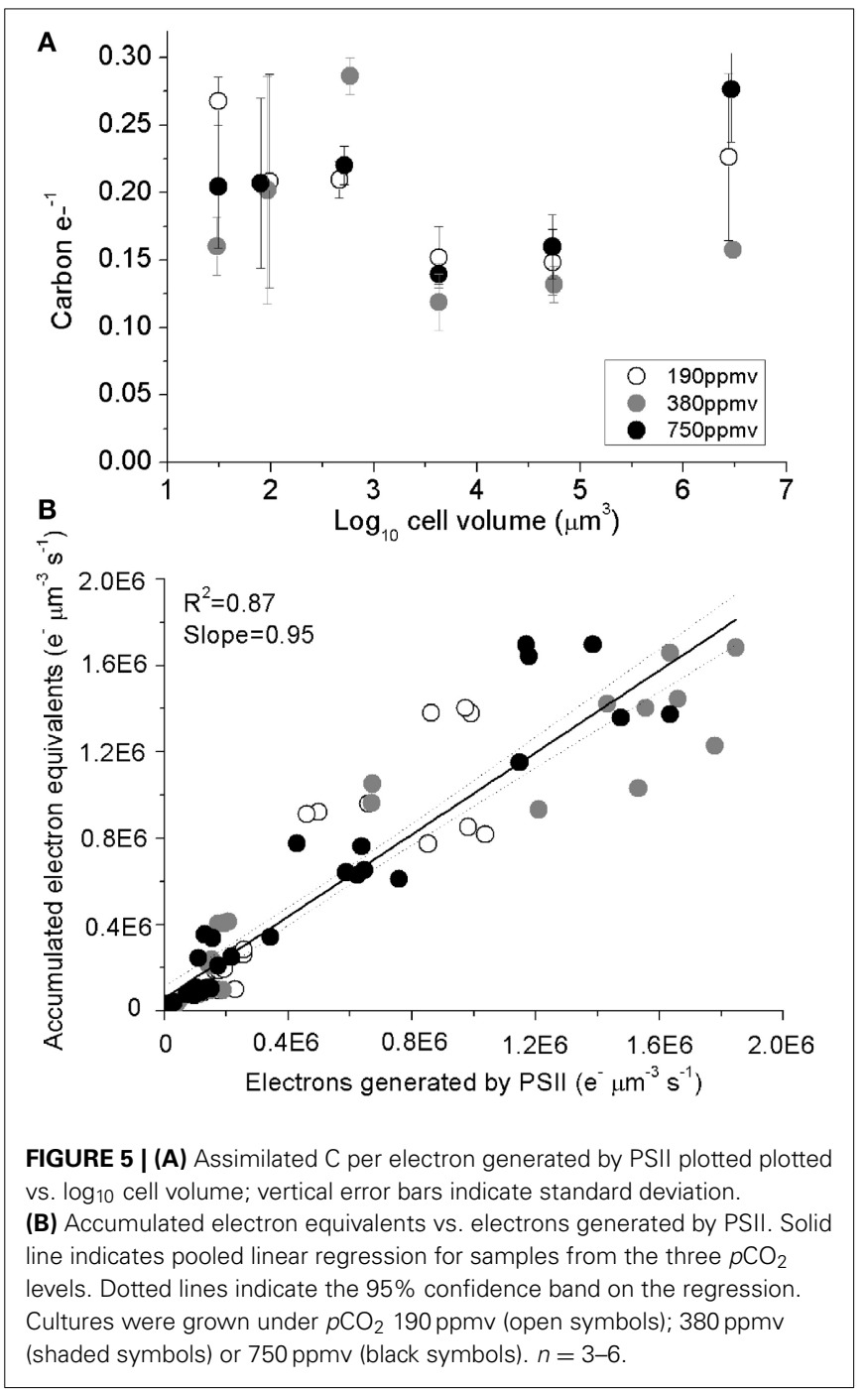

acid 46 had a median cell biovolume of $\sim 88 \mu \mathrm{m}^{3}$ compared to the 6 taxa with SYWEL with a median cell biovolume of $\sim 3043 \mu \mathrm{m}^{3}$ ( $p=0.08$ ). In parallel RbcL position 171 , also annotated as falling at the RbcL:RbcS heterodimer interface, shifts from NKYGTP conserved across the smaller Thalassiosira lineages (NCBI gi118411104, gi315320529, gi98990579, gi98990561, gi98990595) to NKYGIP in Thalassiosira weissflogii (NCBI gi98990581) and to NKYGAP in the large Coscinodiscus wailesii (NCBI gi329343318). Similarly, an even wider alignment of diatom RbcL sequences for which we had cell size estimates $(N=$ 390) (Finkel, 2007) showed that the 152 taxa with NKYGTP had a median cell biovolume of $\sim 132 \mu \mathrm{m}^{3}$, compared to a median cell biovolume of $\sim 452 \mu \mathrm{m}^{3}$ for the 238 taxa with a hydrophobic amino acid such as I at position 171.

Even though we cannot yet discern the cause(s) for the decreasing C-assimilation per RUBISCO with increasing cell size, larger centric diatoms allocate an increased fraction of their total cellular nitrogen to RUBISCO, and this increase largely offsets the slower achieved C-assimilation rates per unit RUBISCO enzyme.

The reductant equivalents accumulated in the form of cellular $\mathrm{C}$ and $\mathrm{N}$ represented about $95 \%$ of the estimated electrons 
generated by PSII, across our diatom size spectrum. This ratio is high compared to other studies based upon ${ }^{14} \mathrm{C}$ uptake or oxygen evolution (Suggett et al., 2009; Halsey et al., 2010, 2013; Lawrenz et al., 2013). Our estimate of cellular C and N was based upon total Particulate Organic Carbon and Particulate Organic Nitrogen, and so likely exaggerates the actual content of $\mathrm{C}$ and $\mathrm{N}$ from those living cells that contribute to the estimate of photosynthetic electron transport, since our cultures contained some dead cells (Agusti and Sanchez, 2002) and other debris. Even so, the ratio of accumulated to generated reductant did not vary with cell size nor with $p \mathrm{CO}_{2}$ treatment, indicating a conserved allocation of photosynthetically derived reductant to total $\mathrm{C}$ on a per cell volume basis, at least for diatoms under nutrient and light repletion. Furthermore, Antarctic diatoms (Young et al., 2015) during a bloom approached our estimates for the ratio of accumulated reductant per generated electrons, estimated over a diel cycle (Lawrenz et al., 2013) supporting the validity of our approach.

Nitrogen allocation to the macromolecular complexes of the photosynthetic apparatus now represents a predictably size dependent biosynthetic cost for diatoms. We show that large diatoms incur a higher demand upon their nitrogen metabolism capacity to accumulate larger pools of RUBISCO, apparently to counter their slower achieved carbon uptake per RUBISCO. Thus, in addition to the cost of decreased light harvesting per unit chlorophyll imposed by optical packaging, slower C-uptake per RUBISCO places a further size-dependent burden upon phytoplankton nitrogen metabolism, thereby reinforcing the competitive disadvantage upon larger cells relative to smaller cells in acquiring the key resources required for photosynthesis. Our experimentally derived outcome for centric diatoms is consistent with observations of their distribution in the open ocean; specifically, larger centric diatom species appear restricted to deeper depths closer to the nutricline whereas smaller species are more abundant in the high light-low nutrient waters (Venrick, 2002). The size-dependent increase in the burden upon nitrogen metabolism could also explain why some larger diatoms form associations with $\mathrm{N}_{2}$-fixing bacteria in open ocean surface waters (Zehr et al., 2000; Foster et al., 2011). We therefore suggest that the combined burdens of not only light harvesting but also $\mathrm{CO}_{2}$ acquisition upon nitrogen metabolism may place an effective upper limit on the cell size that can sustain growth of diatoms.

\section{ACKNOWLEDGMENTS}

This work was funded by NSERC Canada Discovery and Canada Research Chair funding to Zoe V. Finkel and Douglas A. Campbell. Yaping Wu was supported by the National Natural Science Foundation of China (No. 41206091, 41476093). Jennifer Jeans was supported by a Mount Allison University Rice Graduate Scholarship and by an NSERC Canada Post Graduate Scholarship. The authors thank the two reviewers for generously extensive comments that helped us improve the manuscript.

\section{REFERENCES}

Agusti, S., and Sanchez, M. C. (2002). Cell viability in natural phytoplankton communities quantified by a membrane permeability probe. Limnol. Oceanogr. 47, 818-828. doi: 10.4319/lo.2002.47.3.0818
Amunts, A., Toporik, H., Borovikova, A., and Nelson, N. (2010). Structure determination and improved model of plant photosystem I. J. Biol. Chem. 285, 3478-3486. doi: 10.1074/jbc.M109.072645

Armbrust, E. V., Berges, J. A., Bowler, C., Green, B. R., Martinez, D., Putnam, N. H., et al. (2004). The genome of the diatom Thalassiosira Pseudonana: ecology, evolution, and metabolism. Science 306, 79-86. doi: 10.1126/science.1101156

Badger, M. R., Andrews, T. J., Whitney, S. M., Ludwig, M., Yellowlees, D. C., Leggat, W., et al. (1998). The diversity and coevolution of Rubisco, plastids, pyrenoids, and chloroplast-based $\mathrm{CO}_{2}$-concentrating mechanisms in algae. Can. J. Bot. 76, 1052-1071. doi: 10.1139/b98-074

Badger, M. R., and Bek, E. J. (2007). Multiple Rubisco forms in proteobacteria: their functional significance in relation to $\mathrm{CO}_{2}$ acquisition by the $\mathrm{CBB}$ cycle. J. Exp. Bot. 59, 1525-1541. doi: 10.1093/jxb/erm297

Baniulis, D., Yamashita, E., Zhang, H., Hasan, S. S., and Cramer, W. A. (2008). Structure-function of the cytochrome b6f complex. Photochem. Photobiol. 84, 1349-1358. doi: 10.1111/j.1751-1097.2008.00444.x

Beardall, J., Sobrino, C., and Stojkovic, S. (2009). Interactions between the impacts of ultraviolet radiation, elevated $\mathrm{CO}_{2}$, and nutrient limitation on marine primary producers. Photochem. Photobiol. Sci. 8, 1257. doi: 10.1039/b9pp00034h

Boelen, P., van de Poll, W. H., van der Strate, H. J., Neven, I. A., Beardall, J., and Buma, A. G. J. (2011). Neither elevated nor reduced $\mathrm{CO}_{2}$ affects the photophysiological performance of the marine Antarctic diatom Chaetoceros brevis. J. Exp. Mar. Biol. Ecol. 406, 38-45. doi: 10.1016/j.jembe.2011.06.012

Brading, P., Warner, M. E., Smith, D. J., and Suggett, D. J. (2013). Contrasting modes of inorganic carbon acquisition amongst Symbiodinium (Dinophyceae) phylotypes. New Phytol. 107, 432-442. doi: 10.1111/nph.12379

Brown, C., MacKinnon, J., Cockshutt, A., Villareal, T., and Campbell, D. (2008). Flux capacities and acclimation costs in Trichodesmium from the Gulf of Mexico. Mar. Biol. 154, 413-422. doi: 10.1007/s00227-008-0933-z

Burkhardt, S., Riebesell, U., and Zondervan, I. (1999). Effects of growth rate, $\mathrm{CO}_{2}$ concentration, and cell size on the stable carbon isotope fractionation in marine phytoplankton. Geochim. Cosmochim. Acta 63, 3729-3741. doi: 10.1016/S00167037(99)00217-3

Campbell, D. A., Cockshutt, A. M., and Porankiewicz-Asplund, J. (2003). Analysing photosynthetic complexes in uncharacterized species or mixed microalgal communities using global antibodies. Physiol. Plant. 119, 322-327. doi: 10.1034/j.1399-3054.2003.00175.x

Dortch, Q., Claytonm, J. R. Jr., Thoresen, S. S., and Ahmed, S. I. (1984). Species differences in accumulation of nitrogen pools in phytoplankton. Mar. Biol. 81, 237-250. doi: 10.1007/BF00393218

Falkowski, P., Fenchel, T., and Delong, E. (2008). The microbial engines that drive earth's biogeochemical cycles. Science 320, 1034-1039. doi: 10.1126/science. 1153213

Falkowski, P. G. (1981). Light-shade adaptation and assimilation numbers. J. Plankton Res. 3, 203-216. doi: 10.1093/plankt/3.2.203

Finkel, Z. (2001). Light absorption and size scaling of light limited metabolism in marine diatoms. Limnol. Oceanogr. 46, 86-94. doi: 10.4319/lo.2001.46.1.0086

Finkel, Z. V. (2007). "Does phytoplankton size matter? The evolution of modern marine food webs," in Evolution of Primary Producers in the Sea, eds P. G. Falkowski and A. H. Knoll (Amsterdam; Boston: Elsevier Academic Press), 334-345.

Finkel, Z. V., Beardall, J., Flynn, K. J., Quigg, A., Rees, T. A. V., and Raven, J. A. (2010). Phytoplankton in a changing world: cell size and elemental stoichiometry. J. Plankton Res. 32, 119-137. doi: 10.1093/plankt/fbp098

Foster, R. A., Kuypers, M. M. M., Vagner, T., Paerl, R. W., Musat, N., and Zehr, J. P. (2011). Nitrogen fixation and transfer in open ocean diatom-cyanobacterial symbioses. ISME J. 5, 1484-1493. doi: 10.1038/ismej.2011.26

Gao, K., and Campbell, D. A. (2014). Photophysiological responses of marine diatoms to elevated $\mathrm{CO}_{2}$ and decreased pH: a review. Funct. Plant Biol. 41, 449. doi: 10.1071/FP13247

Gao, K., Xu, J., Gao, G., Li, Y., Hutchins, D. A., Huang, B., et al. (2012). Rising $\mathrm{CO}_{2}$ and increased light exposure synergistically reduce marine primary productivity. Nat. Clim. Change 2, 519-523. doi: 10.1038/nclimate1507

Gavis, J. (1976). Munk and Riley revisited: nutrient diffusion transport and rates of phytoplankton growth. J. Mar. Res. 34, 161-179.

Giordano, M., Beardall, J., and Raven, J. A. (2005). $\mathrm{CO}_{2}$ CONCENTRATING MECHANISMS IN ALGAE: mechanisms, environmental modulation, and evolution. Annu. Rev. Plant Biol. 56, 99-131. doi: 10.1146/annurev.arplant.56.032604.144052 
Gotoh, E., Kobayashi, Y., and Tsuyama, M. (2010). The post-illumination chlorophyll fluorescence transient indicates the RuBP regeneration limitation of photosynthesis in low light in Arabidopsis. FEBS Lett. 584, 3061-3064. doi: 10.1016/j.febslet.2010.05.039

Gruber, N., and Galloway, J. N. (2008). An Earth-system perspective of the global nitrogen cycle. Nature 451, 293-296. doi: 10.1038/nature06592

Halsey, K. H., Milligan, A. J., and Behrenfeld, M. J. (2010). Physiological optimization underlies growth rate-independent chlorophyll-specific gross and net primary production. Photosynth. Res. 103, 125-137. doi: 10.1007/s11120-0099526-z

Halsey, K. H., O’Malley, R. T., Graff, J. R., Milligan, A. J., and Behrenfeld, M. J. (2013). A common partitioning strategy for photosynthetic products in evolutionarily distinct phytoplankton species. New Phytol. 198, 1030-1038. doi: 10.1111/nph.12209

Hopkinson, B. M., Dupont, C. L., Allen, A. E., and Morel, F. M. M. (2011). Efficiency of the $\mathrm{CO}_{2}$-concentrating mechanism of diatoms. Proc. Natl. Acad. Sci. U.S.A. 108, 3830-3837. doi: 10.1073/pnas.1018062108

Irwin, A. J., Finkel, Z. V., Schofield, O. M. E., and Falkowski, P. G. (2006). Scaling-up from nutrient physiology to the size-structure of phytoplankton communities. J. Plankton Res. 28, 459-471. doi: 10.1093/plankt/fbi148

Jeffrey, S., and Humphrey, G. (1975). New spectrophotometric equations for determining chlorophylls a1, b1, c1 and c2 in higher plants, algae and natural phytoplankton. Biochem. Physiol. Pflanz. 167, 191-194.

Key, T., McCarthy, A., Campbell, D. A., Six, C., Roy, S., and Finkel, Z. V. (2010). Cell size trade-offs govern light exploitation strategies in marine phytoplankton. Environ. Microbiol. 12, 95-104. doi: 10.1111/j.1462-2920.2009.02046.x

Kirk, J. T. O. (1994). Light and Photosynthesis in Aquatic Ecosystems, 2nd Edn. Cambridge; New York, NY: Cambridge University Press.

Kolber, Z. S., Prášil, O., and Falkowski, P. G. (1998). Measurements of variable chlorophyll fluorescence using fast repetition rate techniques: defining methodology and experimental protocols. Biochim. Biophys. Acta 1367, 88-106. doi: 10.1016/S0005-2728(98)00135-2

Kromkamp, J. C., Dijkman, N. A., Peene, J., Simis, S. G. H., and Gons, H. J. (2008). Estimating phytoplankton primary production in Lake IJsselmeer (The Netherlands) using variable fluorescence (PAM-FRRF) and C-uptake techniques. Eur. J. Phycol. 43, 327-344. doi: 10.1080/09670260802080895

Kroon, B. M. A., and Thoms, S. (2006). From electron to biomass: a mechanistic model to describe phytoplankton photosynthesis and steady-state growth rates. J. Phycol. 42, 593-609. doi: 10.1111/j.1529-8817.2006.00221.x

Laney, S. R. (2003). Assessing the error in photosynthetic properties determined with fast repetition rate fluorometry. Limnol. Oceanogr. 48, 2234-2242. doi: 10.4319/lo.2003.48.6.2234

Langer, G., Geisen, M., Baumann, K., Kläs, J., Riebesell, U., Thoms, S., et al. (2006). Species-specific responses of calcifying algae to changing seawater carbonate chemistry. Geochem. Geophys. Geosystems 7, 1-12. doi: 10.1029/2005GC 001227

Lawrenz, E., Silsbe, G., Capuzzo, E., Ylöstalo, P., Forster, R. M., Simis, S. G. H., et al. (2013). Predicting the electron requirement for carbon fixation in seas and oceans. PLoS ONE 8:e58137. doi: 10.1371/journal.pone.0058137

LeBlanc, K., Arstequ, J., Armand, L., Assmy, P., Beker, B., Bode, A., et al. (2012). A global diatom database-abundance, biovolume and biomass in the world ocean. Earth Syst. Sci. Data 4, 149-165. doi: 10.5194/essd-4-149-2012

Li, G., Brown, C. M., Jeans, J., Donaher, N., McCarthy, A., and Campbell, D. A. (2014). The Nitrogen costs of photosynthesis in a diatom under current and future $\mathrm{pCO}_{2}$. New Phytol. doi: 10.1111/nph.13037. [Epub ahead of print].

Li, G., and Campbell, D. (2013). Rising $\mathrm{CO}_{2}$ Interacts with growth light and growth rate to alter Photosystem II photoinactivation of the coastal diatom Thalassiosira pseudonana. PLoS ONE 8:e55562. doi: 10.1371/journal.pone.0055562

López-Sandoval, D., Rodríguez-Ramos, T., Cermeño, P., and Marañón, E. (2013). Exudation of organic carbon by marine phytoplankton: dependence on taxon and cell size. Mar. Ecol. Prog. Ser. 477, 53-60. doi: 10.3354/meps10174

Losh, J. L., Young, J. N., and Morel, F. M. M. (2013). Rubisco is a small fraction of total protein in marine phytoplankton. New Phytol. 198, 52-58. doi: $10.1111 / \mathrm{nph} .12143$

Marañón, E., Cermeño, P., López-Sandoval, D. C., Rodríguez-Ramos, T., Sobrino, C., Huete-Ortega, M., et al. (2013). Unimodal size scaling of phytoplankton growth and the size dependence of nutrient uptake and use. Ecol. Lett. 16, 371-379. doi: 10.1111/ele.12052
Marañón, E., Cermeno, P., Rodriquez, J., Zubkov, M. V., and Harris, R. P. (2007). Scaling of phytoplankton photosynthesis and cell size in the ocean. Limnol. Oceanogr. 52, 2190-2198. doi: 10.4319/lo.2007.52.5.2190

McCarthy, A., Rogers, S. P., Duffy, S. J., and Campbell, D. A. (2012). Elevated carbon dioxide differentially alters the photophysiology of Thalassiosira pseudonana (Bacillariophyceae) and Emiliana huxleyi (Haptophyta). J. Phycol. 48, 635-646. doi: 10.1111/j.1529-8817.2012.01171.x

Mizohata, E., Matsumura, H., Okano, Y., Kumei, M., Takuma, H., Onodera, J., et al. (2002). Crystal structure of activated ribulose-1,5-bisphosphate carboxylase/oxygenase from green alga Chlamydomonas reinhardtii complexed with 2-carboxyarabinitol-1,5-bisphosphate. J. Mol. Biol. 316, 679-691. doi: 10.1006/jmbi.2001.5381

Moore, C. M., Mills, M. M., Arrigo, K. R., Berman-Frank, I., Bopp, L., Boyd, P. W., et al. (2013). Processes and patterns of oceanic nutrient limitation. Nat. Geosci. 6, 701-710. doi: 10.1038/ngeo1765

Morel, A., and Bricaud, A. (1981). Theoretical results concerning light absorption in a discrete medium, and application to specific absorption of phytoplankton. Deep Sea Res. Part Oceanogr. Res. Pap. 28, 1375-1393. doi: 10.1016/01980149(81)90039-X

Mott, K. A., Jensen, R. G., O’Leary, J. W., and Berry, J. A. (1984). Photosynthesis and Ribulose 1,5-bisphosphate concentrations in intact leaves of xanthium strumarium L. Plant Physiol. 76, 968-971.

Mullin, M. M., Sloan, P. R., and Eppley, R. W. (1966). Relationship between carbon content, cell volume and area in phytoplankton. Limnol. Oceanogr. 11, 307-310.

Nagao, R., Takahashi, S., Suzuki, T., Dohmae, N., Nakazato, K., and Tomo, T. (2013). Comparison of oligomeric states and polypeptide compositions of fucoxanthin chlorophyll a/c-binding protein complexes among various diatom species. Photosynth. Res. 117, 281-288. doi: 10.1007/s11120-013-9903-5

Pasciak, W. J., and Gavis, J. (1974). Transport limitation of nutrient uptake in phytoplankton. Limnol. Ocean. 19, 881-888.

Pierrot, D., Lewis, E., and Wallace, D. W. R. (2006). MS Excel Program Developed for CO2 System Calculations. Oak Ridge, TN: ORNL/CDIAC-105a. Carbon Dioxide Information Analysis Center, Oak Ridge National Laboratory, U.S. Department of Energy. doi: 10.3334/CDIAC/otg.CO2SYS_XLS_CDIAC105a

Premvardhan, L., Robert, B., Beer, A., and Büchel, C. (2010). Pigment organization in fucoxanthin chlorophyll a/c2 proteins (FCP) based on resonance Raman spectroscopy and sequence analysis. Biochim. Biophys. Acta 1797, 1647-1656. doi: 10.1016/j.bbabio.2010.05.002

Raven, J. A. (1984). A cost-benefit analysis of photon absorption by photosynthetic unicells. New Phytol. 98, 593-625.

Raven, J. A. (2013). Rubisco: still the most abundant protein of Earth? New Phytol. 198, 1-3. doi: 10.1111/nph.12197

Raven, J. A., Beardall, J., and Giordano, M. (2014). Energy costs of carbon dioxide concentrating mechanisms in aquatic organisms. Photosynth. Res. 121, 111-124. doi: 10.1007/s11120-013-9962-7

Raven, J. A., Giordano, M., Beardall, J., and Maberly, S. C. (2011). Algal and aquatic plant carbon concentrating mechanisms in relation to environmental change. Photosynth. Res. 109, 281-296. doi: 10.1007/s11120-011-9632-6

Riebesell, U., Fabry, V. J., Hansson, L., and Gattuso, J.-P. (2010). Guide to Best Practices for Ocean Acidification Research and Data Reporting, eds U. Riebesell, V. J. Fabry, L. Hansson, and J.-P. Gattuso (Luxembourg: Publications Office of the European Union). Available online at: http://www.epoca-project.eu/ index-php/guide-to-best-practices-for-ocean-acidification-research-and-datareporting.html (Accessed October 24, 2014).

Rost, B., Zondervan, I., and Wolf-Gladrow, D. (2008). Sensitivity of phytoplankton to future changes in ocean carbonate chemistry: current knowledge, contradictions and research directions. Mar. Ecol. Prog. Ser. 373, 227-237. doi: 10.3354/meps07776

Schippers, P., Lürling, M., and Scheffer, M. (2004). Increase of atmospheric $\mathrm{CO}_{2}$ promotes phytoplankton productivity. Ecol. Lett. 7, 446-451. doi: 10.1111/j.1461-0248.2004.00597.x

Shi, T., and Falkowski, P. G. (2008). Genome evolution in cyanobacteria: the stable core and the variable shell. Proc. Natl. Acad. Sci. U.S.A. 105, 2510-2515. doi: 10.1073/pnas.0711165105

Stolte, W., and Riegman, R. (1995). Effect of phytoplankton cell size on transientstate nitrate and ammonium uptake kinetics. Microbiology 141, 1221-1229. doi: 10.1099/13500872-141-5-1221 
Suggett, D., MacIntyre, H., and Geider, R. (2004). Evaluation of biophysical and optical determinations of light absorption by photosystem II in phytoplankton. Limnol. Oceanogr. Methods 2, 316-332. doi: 10.4319/lom.2004. 2.316

Suggett, D., MacIntyre, H., Kana, T., and Geider, R. (2009). Comparing electron transport with gas exchange: parameterising exchange rates between alternative photosynthetic currencies for eukaryotic phytoplankton. Aquat. Microb. Ecol. 56, 147-162. doi: 10.3354/ame01303

Tortell, P. D., and Morel, F. M. M. (2002). Sources of inorganic carbon for phytoplankton in the eastern subtropical and equatorial pacific ocean. Limnol. Oceanogr. 47, 1012-1022. doi: 10.4319/lo.2002.47.4.1012

Tortell, P. D., Rau, G. H., and Morel, F. M. M. (2000). Inorganic carbon acquisition in coastal Pacific phytoplankton communities. Limnol. Oceanogr. 45, 1485-1500. doi: 10.4319/lo.2000.45.7.1485

Trimborn, S., Brenneis, T., Sweet, E., and Rost, B. (2013). Sensitivity of Antarctic phytoplankton species to ocean acidification: growth, carbon acquisition, and species interaction. Limnol. Oceanogr. 58, 997-1007. doi: 10.4319/lo.2013.58.3.0997

Trimborn, S., Wolf-Gladrow, D., Richter, K.-U., and Rost, B. (2009). The effect of $p \mathrm{CO}_{2}$ on carbon acquisition and intracellular assimilation in four marine diatoms. J. Exp. Mar. Biol. Ecol. 376, 26-36. doi: 10.1016/j.jembe.2009. 05.017

Umena, Y., Kawakami, K., Shen, J.-R., and Kamiya, N. (2011). Crystal structure of oxygen-evolving photosystem II at a resolution of 1.9?A. Nature 473, 55-60. doi: 10.1038 /nature09913

Venrick, E. L. (2002). Floral patterns in the California current system off southern California: 1990-1996. J. Mar. Res. 60, 171-189. doi: $10.1357 / 002224002762341294$

Wu, Y., Campbell, D. A., Irwin, A. J., Suggett, D. J., and Finkel, Z. V. (2014). Ocean acidification enhances the growth rate of larger diatoms. Limnol. Oceanogr. 59, 1027-1034. doi: 10.4319/lo.4014.59.3.1027
Young, J. N., Goldman, J. A. L., Kranz, S. A., Tortell, P. D., and Morel, F. M. M. (2015). Slow carboxylation of Rubisco constrains the maximum rate of carbon fixation during Antarctic phytoplankton blooms. New Phytol. 205, 172-181. doi: 10.1111/nph.13021

Young, J. N., Rickaby, R. E. M., Kapralov, M. V., and Filatov, D. A. (2012). Adaptive signals in algal Rubisco reveal a history of ancient atmospheric carbon dioxide. Philos. Trans. R. Soc. B Biol. Sci. 367, 483-492. doi: 10.1098/rstb.20 11.0145

Zehr, J. P., Carpenter, E. J., and Villareal, T. A. (2000). New perspectives on nitrogen-fixing microorganisms in tropical and subtropical oceans. Trends Microbiol. 8, 68-73. doi: 10.1016/S0966-842X(99)01670-4

Conflict of Interest Statement: Dr. Douglas A. Campbell is a minority shareholder in the company Environmental Proteomics NB that provided some of the antibodies and protein quantitation standards used in this work. The authors declare that the research was conducted in the absence of any commercial or financial relationships that could be construed as a potential conflict of interest.

Received: 17 September 2014; accepted: 17 November 2014; published online: 09 December 2014.

Citation: Wu Y, Jeans J, Suggett DJ, Finkel ZV and Campbell DA (2014) Large centric diatoms allocate more cellular nitrogen to photosynthesis to counter slower RUBISCO turnover rates. Front. Mar. Sci. 1:68. doi: 10.3389/fmars.2014.00068

This article was submitted to Global Change and the Future Ocean, a section of the journal Frontiers in Marine Science.

Copyright (C) 2014 Wu, Jeans, Suggett, Finkel and Campbell. This is an open-access article distributed under the terms of the Creative Commons Attribution License (CC BY). The use, distribution or reproduction in other forums is permitted, provided the original author(s) or licensor are credited and that the original publication in this journal is cited, in accordance with accepted academic practice. No use, distribution or reproduction is permitted which does not comply with these terms. 